\title{
Distribution patterns of hepatitis B surface antigen (HBsAg) in the liver of hepatitis patients
}

\author{
M. B. RAY, V. J. DESMET, J. FEVERY, J. DE GROOTE, A. F. BRADBURNE, \\ AND J. DESMYTER \\ From the Laboratory of Histochemistry and Cytochemistry and the Division of Hepatology \\ (Department of Medical Investigation) and the Viral Diseases Laboratory (Department of Human Biology), \\ Akademisch Ziekenhuis Sint Rafaël, University of Leuven, B-3000 Leuven, Belgium
}

SYNOPSIS One hundred liver biopsies from 100 hepatitis patients were examined by the indirect immunofluorescent technique for the detection of HBsAg. Of the 60 positive specimens 52 were diagnosed as various types of chronic hepatitis and 8 were acute hepatitis. Four main distribution patterns of HBsAg were obtained: full cytoplasmic fluorescence with diffuse lobular distribution; cytoplasmic fluorescence with spotty distribution;peripheral fluorescence in the cell membraneand/or cell peripheries; and focal cytoplasmic positivity. There was an inverse relationship between the number of positive hepatocytes and the extent of liver cell necrosis. The distribution patterns of HBsAg were distinctive in each type of chronic hepatitis and in acute hepatitis. Homogeneous full cytoplasmic fluorescence, distributed diffusely in the whole liver lobule, was observed in chronic persistent hepatitis and in cirrhosis with little activity whereas peripheral liver cell membrane and/or peripheral cytoplasmic fluorescence associated with cytoplasmic positivity in a smaller number of hepatocytes was a characterisitic finding in chronic aggressive hepatitis, active cirrhosis, and acute hepatitis with possible transition to chronicity. Focal cytoplasmic fluorescence was observed in acute hepatitis and in a group of biopsies in chronic hepatitis in which HBsAg was detected in the liver but no antigen was detectable in the serum. The results show that the different patterns of distribution of HBsAg in the liver biopsy are helpful for the histological diagnosis of different types of HBAg positive viral hepatitis and are consistent with the hypothesis of the role of specific immune response in the pathogenesis of type $B$ viral hepatitis.

Acute and chronic viral hepatitis have distinctive histological features (Desmet, 1970). In chronic hepatitis the amount of mononuclear cell infiltration in and around the portal fields and the extent of liver cell damage indicate the stage and the severity of the disease. On the other hand, predominant hepatocellular necrosis in the centrilobular area with less impressive portal infiltration, along with the accumulation of ceroid-containing macrophages, determine the stages of acute hepatitis (Bianchi et al, 1971). Both acute and chronic viral hepatitis are associated with hepatitis B antigen (HBAg) (Blumberg et al, 1967; Prince, 1968). The genesis of the diverse histological pictures of $\mathrm{HBAg}$ associated hepatitis is unknown but it has been postulated that this may be the result of varied host-virus interreac-

Received for publication 26 August 1975 tions (Blumberg et al, 1970; Dudley et al, 1972). On the basis of this hypothesis one would expect at least some variance in the pattern of intrahepatic localization of HBAg in various types of hepatitis B. In order to obtain some insight in the different patterns of localization and in the role played by HBAg in the development of various types of hepatitis, a prospective immunofluorescent study was performed on the liver biopsies of 100 patients with both acute and chronic hepatitis.

\section{Material and Methods}

One hundred liver biopsies from 100 hepatitis patients submitted to needle biopsy during the last two years were included in this study. The biopsies have been classified as outlined in the preceding paper (Ray et al, 1976). The procedure for the collection of the biopsies, freezing, cutting, and processing 
for immunofluorescence have already been reported (Ray et al, 1974).

The indirect immunofluorescent technique was applied for the detection of hepatitis B surface antigen (HBsAg) in the liver tissue; the technical details, including the application of different controls, were described earlier (Ray et al, 1974). Specific anti HBsAg from rabbit (Behringwerk, Brussels) was obtained commercially. In immunodiffusion it gave reaction to identity with known HBsAg, and gave no reaction when tested for the presence of anticore (anti-HBcAg) in counter immunoelectrophoresis. Moreover, the antiserum gave no nuclear fluorescence when tested on a liver specimen known to contain core particles. Therefore, it was considered specific for HBsAg. Fluorescein-conjugated (FITC) anti rabbit globulins were obtained from Hyland (Brussels).

\section{Results}

Of the 100 biopsies with a histological diagnosis of hepatitis, 60 showed positive fluorescence for HBsAg, 52 cases of chronic hepatitis and 8 cases of acute hepatitis. Of the 52 chronic hepatitis cases, 40 had HBsAg in the serum, while this determination was negative in the remaining 12 . The frequency of HBsAg in this group of hepatitis patients, as estimated by both immunofluorescence in the liver tissue and radioimmunoassay in the serum, and the clinical and biochemical correlations between the antigen positive and negative groups were the subject of a separate report (Ray et al, 1976).

As described previously, $\mathrm{HBsAg}$ was found in the cytoplasm of the hepatocytes (Ray et al, 1974; Ray and Desmet, 1975). The distribution pattern of HBsAg in the hepatocytes was distinctive for both acute and chronic hepatitis. The results obtained with immunofluorescence are summarized in the table.
CHRONIC PERSISTENT HEPATITIS (CPH)

Approximately $60-70 \%$ of the hepatocytes were positive for $\mathrm{HBsAg}$, and the fluorescent cells were mostly diffusely distributed all over the liver lobule. Sometimes isolated islands of positive hepatocytes were also observed. The fluorescence was of very strong intensity and dense homogeneous appearance (fig 1). These dense fluorescent globules, occupying a variable but usually large area of the hepatocytic

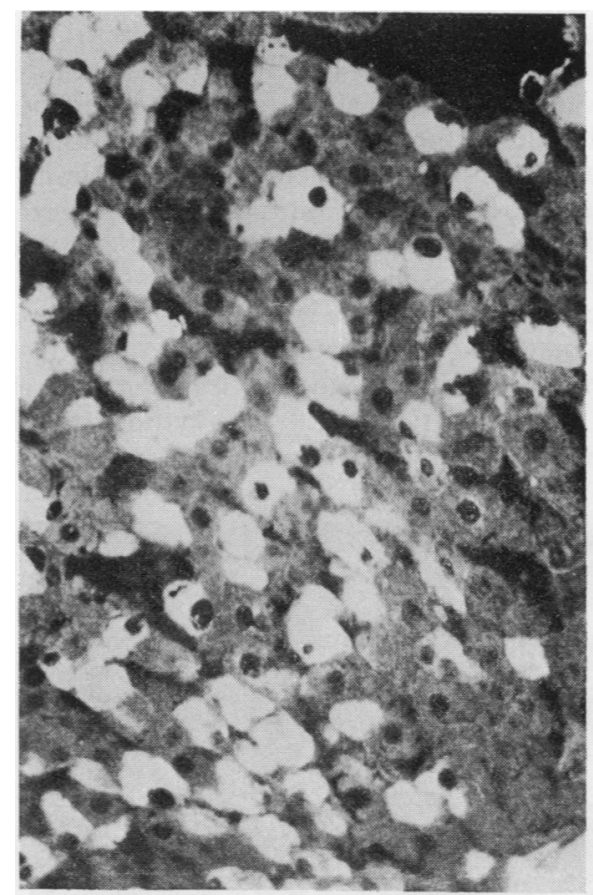

Fig 1. Chronic persistent hepatitis: diffuse homogenous bright fluorescence in the cytoplasm of the hepatocytes distributed diffusely in the liver $(\times 193)$.

\begin{tabular}{|c|c|c|c|c|c|c|}
\hline \multirow[t]{2}{*}{ Histological Diagnosis } & \multirow{2}{*}{$\begin{array}{l}\text { Total } \\
\text { Biopsies }\end{array}$} & \multirow{2}{*}{$\begin{array}{l}\text { Immunofluo- } \\
\text { rescence } \\
\text { Positive }\end{array}$} & \multicolumn{4}{|c|}{ Distribution Pattern } \\
\hline & & & $\begin{array}{l}\text { Diffuse } \\
\text { Lobular }\end{array}$ & Scattered & $\begin{array}{l}\text { Diffuse Cell } \\
\text { Membrare } \\
\text { and/or Cell } \\
\text { Periphery }\end{array}$ & $\begin{array}{l}\text { Focal Cyto- } \\
\text { plasmic }\end{array}$ \\
\hline $\begin{array}{l}\text { Chronic persistent hepatitis } \\
\text { Chronic aggressive hepatitis } \\
\text { Cirrhosis with little activity } \\
\text { Active cirrhosis } \\
\text { Acute hepatitis with signs of possible transi- } \\
\text { tion to chronicity } \\
\text { Fully developed stage of acute hepatitis, } \\
\text { later and residual stage of acute hepatitis }\end{array}$ & $\begin{array}{r}11 \\
20 \\
11 \\
34 \\
5 \\
19\end{array}$ & $\begin{array}{r}6 \\
14 \\
5 \\
27 \\
3 \\
\\
5\end{array}$ & $\begin{array}{l}3 \\
1 \\
3 \\
5 \\
- \\
-\end{array}$ & $\begin{array}{r}11 \\
\frac{11}{15} \\
1 \\
-\end{array}$ & $\begin{array}{r}1 \\
\frac{9}{15} \\
2 \\
-\end{array}$ & $\begin{array}{l}2^{2} \\
2^{2} \\
2^{2} \\
6^{2}+1 \\
- \\
5\end{array}$ \\
\hline
\end{tabular}

Table Summary of distribution pattern of $\mathrm{HBs} A \mathrm{~g}$ in acute and chronic hepatitis

${ }^{1}$ When there was more than one distribution pattern, this was noted.

'Biopsies from patients negative for circulating HBsAg. 
cytoplasm, corresponded to the 'groundglass appearance' in haematoxylin-eosin stained sections (Hadziyannis et al, 1973). Of the six positive biopsies, four showed diffuse homogeneous cytoplasmic fluorescence; one of these also showed a positive cell membrane fluorescence over a significant part of the cell periphery. The remaining two biopsies, from patients who were negative for $\mathrm{HBsAg}$ in the serum, showed specific fluorescence restricted to only a small part of the cytoplasm (focal cytoplasmic fluorescence).

\section{CHRONIC AGgRESSIVE HEPATITIS (CAH)}

In this group of biopsies HBsAg was localized in liver cells with scattered distribution throughout the liver lobule. At the cellular level, the fluorescence was predominantly found in the cell membrane and sometimes encroached on part of the liver cell periphery. The number of fluorescent hepatocytes was strikingly less than in $\mathrm{CPH}$. On most occasions, intracellular fluorescence was confined to only part of the hepatocytic cytoplasm contrary to the full cytoplasmic fluorescence found in $\mathrm{CPH}$ and in cirrhosis with little activity (fig 2). The cytoplasmic fluorescence was dense and homogeneous in character.

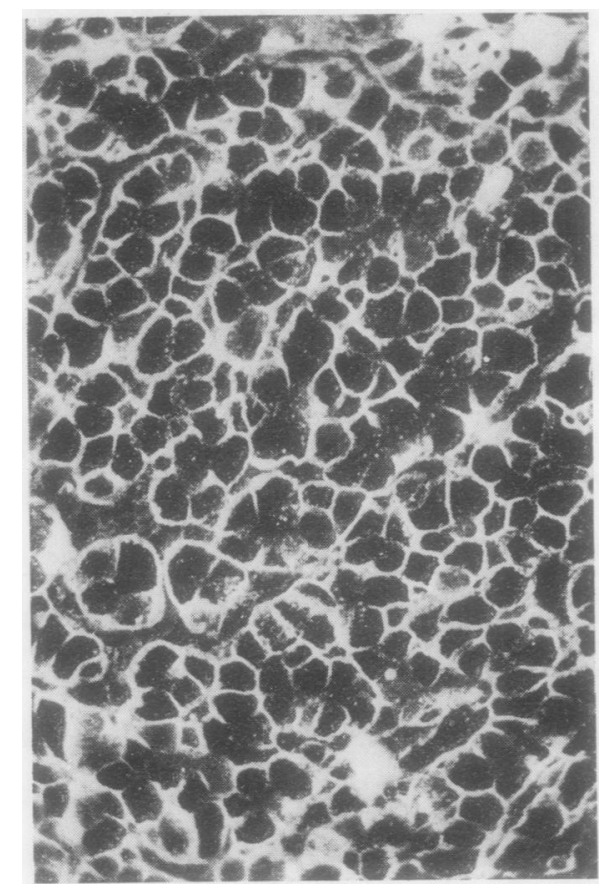

Fig 2 Chronic aggressive hepatitis: HBsAg-specific fluorescence mostly demonstrated in the membrane of the liver cells. In a few hepatocytes the cell membrane along with the cell periphery is also positive; only a few cells show bright cytoplasmic fluorescence $(\times 176)$.
The intensity of the fluorescence in the cell membranes and in the cell periphery was strong and mostly granular. Intense fluorescence was restricted mainly to the sinusoidal pole of the hepatocytes.

Of the 14 positive biopsies, 11 showed the characteristic scattered cell fluorescence (spotty distribution). Nine of these 11 biopsies also showed positive fluorescence in the cell membrane and/or cell peripheries. Only one biopsy showed diffuse cytoplasmic fluorescence. The two biopsies from patients who were negative for HBsAg in the serum but positive in the liver tissue showed focal cytoplasmic positivity.

CIRRHOSIS WITH LITTLE ACTIVITY

The distribution pattern of HBsAg in this group of biopsies was almost the same as that obtained in $\mathrm{CPH}$. Diffuse homogeneous fluorescence was present in $80-90 \%$ of the hepatocytes in the cirrhotic nodules (fig 3). In some cases fluorescent hepatocytes were present diffusely in one part of the biopsy but no positive cells were found in the remaining part. The intersity of the fluorescence was strong, and of similar appearance in the periphery and in the centre of the cirrhotic nodules. Three of the five

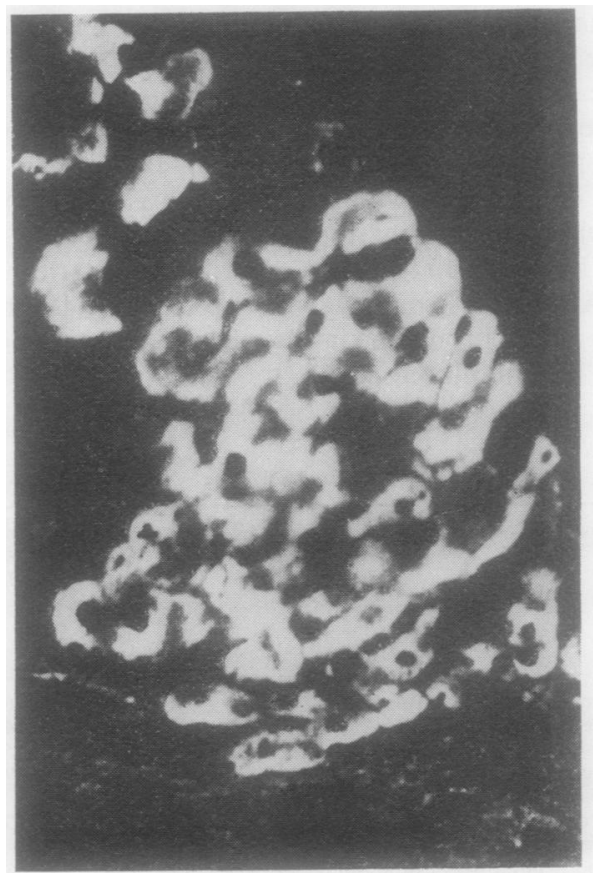

Fig 3 Cirrhosis with 'little activity': bright homogeneous cytoplasmic fluorescence in most of the hepatocytes in a cirrhotic nodule ( . 193). 
positive biopsies showed diffuse cytoplasmic fluorescence, and the remaining two biopsies from serumnegative patients showed focal cytoplasmic fluorescence. No specific fluorescence was detected in the cell membranes.

\section{ACTIVE CIRRHOSIS}

In active cirrhosis the number of positive hepatocytes was noticeably lower than in cirrhosis with little activity, but higher than in CAH. The fluorescent hepatocytes were mostly unevenly distributed over the cirrhotic nodules. The fluorescence was often granular in character and of low intensity, contrary to the strong fluorescence observed in CAH (fig 4). In most cases the liver cell membranes along with part of the peripheral cytoplasm were also positive. In a few instances the fluorescence appeared to be uniformly spread all over the hepatocytic cytoplasm. Of the 27 positive biopsies, 15 showed scattered cell fluorescence and all of them were also positive in the cell membrane and or peripheries. Seven biopsies, six of them from patients who were negative for HBsAg in the serum, showed focal cytoplasmic

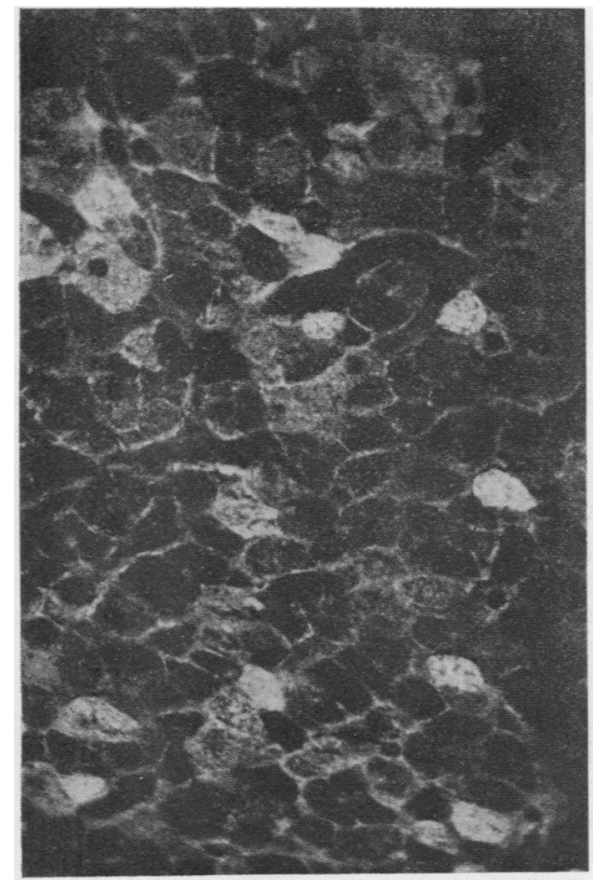

Fig 4 Active cirrhosis: fine granular fluorescence in the cytoplasm and membrane of the hepatocytes. The intensity of the fluorescence is low but the number of positive hepatocytes is large compared to chronic aggressive hepatitis in Fig 2 ( $\times 193)$. fluorescence (fig 5); only five of the positive biopsies showed diffuse cytoplasmic fluorescence without cell membrane positivity.

\section{ACUTE HEPATITIS}

HBsAg containing hepatocytes were found only very rarely in the biopsies of the fully developed stage of acute hepatitis and in the residual and later stages of classical acute hepatitis. In the positive hepatocytes, the antigen was mostly restricted to the perinuclear area and fluorescence was very faint. All the five positive biopsies showed focal cytoplasmic fluorescence.

In acute hepatitis with signs of possible transition to chronicity the distribution patterns of $\mathrm{HBsAg}$ were almost the same as those obtained in CAH. In this group, the number of positive hepatocytes was small and the fluorescence in the cell membrane appeared stronger than that observed in CAH. Two of the three positive biopsies showed fluorescence only in the cell membrane (fig 6) and the remaining single biopsy showed a rare fluorescent cell without cell membrane positivity.

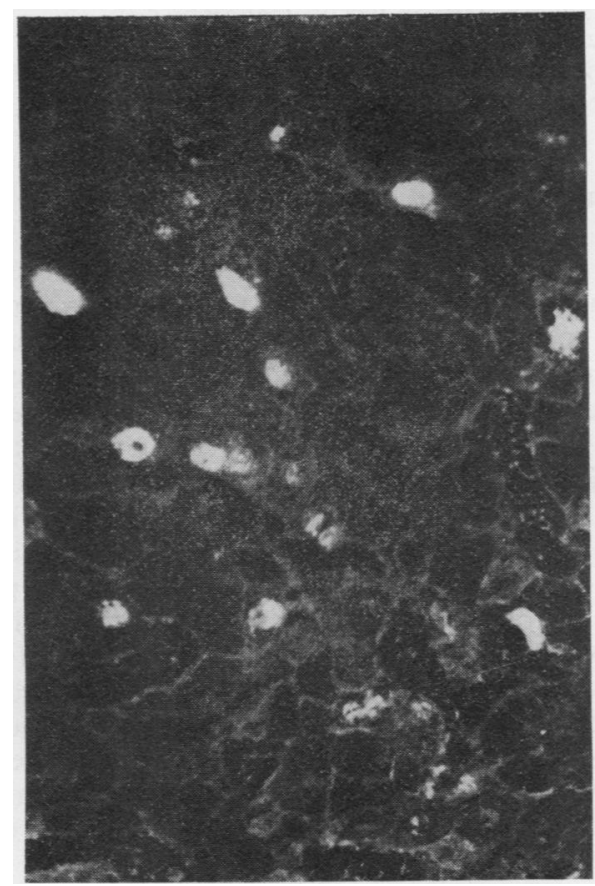

Fig 5 Active cirrhosis with serum negative for $\mathrm{HBs} A \mathrm{~g}$. Specific fluorescence is mostly restricted to a part of the cytoplasm of the liver cells (focal cytoplasmic distribution) ( $\times 193)$. 


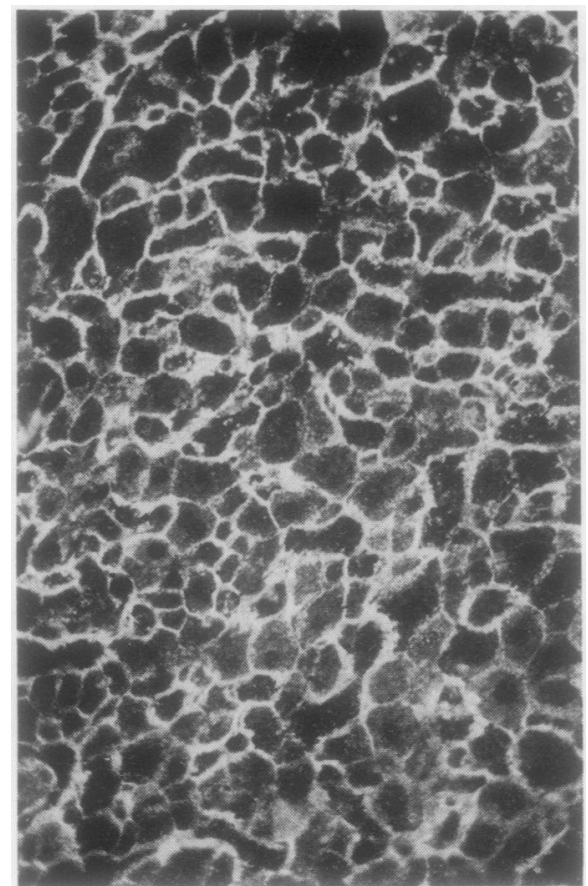

Fig 6 Acute hepatitis with signs of possible transition to chronicity: $\mathrm{HBs} A \mathrm{~g}$ specific fluorescence is localized mainly in the membrane of the hepatocytes. Rarely the antigen was detected in the cytoplasm of the liver cells $(\times 176)$.

\section{Discussion}

The present immunofluorescent study revealed distinctive distribution patterns of $\mathrm{HBsAg}$ in various types of acute and chronic hepatitis. Full cytoplasmic localization with diffuse distribution in the whole liver lobule was observed in the biopsies of CPH and cirrhosis with little activity where there was little or no actual liver cell damage. On the other hand, scattered cell fluorescence occupying variable portions of the hepatocytic cytoplasm and associated with striking hepatocytic membrane and/or peripheral cytoplasmic positivity were the characteristics of CAH and active cirrhosis. In acute hepatitis (with the exception of acute hepatitis with possible transition to chronicity) and in the group of positive biopsies from patients whose serum was negative for HBsAg, fluorescence was mostly found focally in the cytoplasm, either in the perinuclear area or elsewhere, in the form of small aggregates.

The different patterns of HBsAg distribution in hepatitis may be the outcome of varied host-virus interreactions (Blumberg et al, 1970; Dudley et al, 1972; Reed et al, 1974). Such a hypothesis could explain, at least partially, the various reaction patterns of HBsAg observed in this study. The full cytoplasmic fluorescence with diffuse distribution in the whole liver lobule in CPH and cirrhosis with little activity indicates the presence of massive amounts of HBsAg; this may be due to inadequate or totally deficient clearance of the antigen by the host's immunological defence system. These cells apparently release $\mathrm{HBsAg}$ in the bloodstream, since HBsAg could be detected in the serum. The lack of cell membrane localization of HBsAg may prevent these cells from becoming target cells for the immune response. On the other hand, in $\mathrm{CAH}$, active cirrhosis, and acute hepatitis with possible transition to chronicity the amount of antigen is found to be low at the cellular level. In these instances the immune response is adequate to clear most but not all antigen from the liver. The positive cells apparently continue to release HBsAg in the blood, since the antigen could be detected in the serum. The incorporation of $\mathrm{HBsAg}$ in the liver cell membranes or in the liver cell periphery may render these cells recognizable as target cells for the immune response, resulting in cellular necrosis and HBsAg elimination. The membrane expression of HBsAg may further be related to the assembly of Dane particles, since Dane particles (supposedly complete HB virus) are abundant in the serum of patients with CAH as compared to acute hepatitis (Nielsen et al, 1973) and are rare or absent in the serum of 'healthy' HBsAg carriers (Deutsch and Spence, 1972; Nielsen et al, 1972).

In acute hepatitis, very little or no antigen was detected in the liver by immunofluorescence. Our observations and the work done elsewhere both by immunofluorescence (Krawczyński et al, 1972; Cérat et al, 1973; Gudat et al, 1975) and electronmicroscopy (Nelson et al, 1970; Caramia et al, 1972) show that HBsAg was rarely found in biopsies of acute hepatitis B. Although there is always a chance of 'sampling error' in liver biopsy studies, this finding is consistent with the hypothesis that the antigen, or antigen-positive cells, are completely cleared by a normally functioning specific immune system (Dudley et al, 1972).

There is a remarkable correlation between the histological feature of 'piecemeal necrosis' (periportal hepatitis) (Popper and Schaffner, 1971) and liver cell membrane and/or periphery fluorescence for HBsAg. Both occur in acute hepatitis with possible transition to chronicity, CAH, and active cirrhosis. This finding suggests that there may be a causal relationship between the membrane expression of HBsAg on the liver cell periphery and the intralobular infiltration of mononuclear cells, supposed to be immunologically competent cells. The 
focal intracellular fluorescence in liver biopsies from patients with absence of HBsAg in the serum (some cases of CPH and CAH) may reflect intrahepatocytic presence of $\mathrm{HBsAg}$ without actual release of viral components in the bloodstream. This finding indicates that immunofluorescent detection of $\mathrm{HBsAg}$ in the liver tissue is a more reliable technique for identifying 'carriers' of $\mathrm{HB}$ virus than the search for HBsAg in the serum, even when using the most sensitive techniques like radioimmunoassay. The focal intracellular fluorescence in a few hepatocytes in patients with acute hepatitis (supposed to have an adequate immune system for clearance of HB virus) may represent the remaining positive liver cells which escaped destruction during the catastrophe of acute necrotizing hepatitis; the HBsAg was not expressed at the cell's periphery and hence they were not recognized as possible 'target cells'. Continuing HBsAg production and subsequent expression at the cell's periphery may be the mechanism involved in repeated attacks of relapsing hepatitis. This hypothesis would also imply that membrane expression of $\mathrm{HBsAg}$ in liver cells has occurred before the necrotizing episode of acute hepatitis. However, biopsies from patients in their incubation period were not available. The findings may further indicate a direct effect of the immune response on the distribution of HBsAg in the hepatocyte in situ. Evidence that immune interaction may influence the distribution of viral antigens in the infected cell has been obtained recently. Measles antigen in infected HeLa cells is redistributed by human measles antibody to concentrate in polar 'caps' at the cell membrane (Joseph and Oldstone, 1974; Lampert et al, 1975). Although there are obvious differences between the replication cycles of measles and $\mathrm{HB}$ virus, it is tempting to speculate that immune redistribution of $\mathbf{H B}$ antigens in the infected cell might occur; in this respect, our finding that intense fluorescence in $\mathrm{CAH}$ was mainly restricted to the cell periphery of the hepatocyte could be pertinent.

Finally, whatever the explanation of this distinctive distribution of HBsAg in the liver tissue, these findings may be of considerable practical value for refining the histological diagnosis and prognosis in patients with various forms of type B hepatitis (Akeyama et al, 1974).

We acknowledge the valuable help and suggestions of Dr L. Broeckaert and thank Mrs A. De Boeck for technical assistance, Mr M. Rooseleers for preparing the photographs, and Mrs M. VeulemansWeckx for typing the manuscript.

This study was supported by grants from the Nationaal Fonds voor Wetenschappelijk Onderzoek and the Fonds voor Geneeskundig Wetenschappelijk Onderzoek of Belgium.

\section{References}

Akeyama, T., Kamada, T., Koyama, M., and Abe, H. (1974). Distribution patterns of hepatitis $B$ antigen in the liver. Arch. Path., 98, 252-256.

Bianchi, L., De Groote, J., Desmet, V. J., Gedigk, P., Korb, G., Popper, H., Poulsen, H., Scheuer, P. J., Schmid, M., Thaler, H., and Wepler, W. (1971). Morphological criteria in viral hepatitis. Lancet, 1, 333-337.

Blumberg, B. S., Gerstley, B. J. S., Hungerford, D. A., London, W. T., and Sutnick, A. I. (1967). A serum antigen (Australia antigen) in Down's syndrome, leukemia and hepatitis. Ann. intern. Med., 66, 924-931.

Blumberg, B. S., Sutnick, A. I., and London, W. T. (1970). Australia antigen as a hepatitis virus. Variation in host response. Amer. J. Med., 48, 1-8.

Caramia, F., De Bac, C., and Ricci, G. (1972). Virus-like particles within hepatocytes of Australia antigen carriers. Amer. J. Dis. Child., 123, 309-311.

Cérat, G., Richer, G., Viallet, A., Côté, J., Robert, J., and Turgeon, F. (1973). Detection of Australia antigen in liver biopsies by immunofluorescence. Canad. med. Ass. J., 108, 981-984.

Desmet, V. (1970). Histopathology of acute and chronic hepatitis. In The Chronic Hepatitis. Proceedings of the International Course in Hepatology, edited by S. Giorini and D. Mori, pp. 7-23. Fondazione Giovanni Lorenzini, Milan.

Deutsch, G. F. and Spence, L. (1972). Virus-like particles in the liver and their relationship to Australia antigen. (Letter). Lancet, 1, 447.

Dudley, F. J., Fox, R. A., and Sherlock, S. (1972). Cellular immunity and hepatitis-associated Australia antigen liver disease. Lancet, 1, 723-726.

Gudat, F., Bianchi, L., Sonnabend, W., Thiel, G., Aenishaenslin, W., and Stalder, G. A. (1975). Pattern of core and surface expression in liver tissue reflects state of specific immune response in hepatitis B. Lab. Invest., 32, $1-9$.

Hadziyannis, S., Gerber, M. A., Vissoulis, C., and Popper, H. (1973). Cytoplasmic hepatitis B antigen in 'ground glass' hepatocytes of carriers. Arch. Path., 96, 327-330.

Joseph, B. S. and Oldstone, M. B. A. (1974). Antibodyinduced redistribution of measles virus antigens on the cell surface. J. Immunol., 113, 1205-1209.

Krawczyński, K., Nazarewicz, T., Brzosko, W. J., and Nowoslawski, A. (1972). Cellular localization of hepatitisassociated antigen in livers of patients with different forms of hepatitis. J. infect. Dis., 126, 372-377.

Lampert, P. W., Joseph, B. S., and Oldstone, M. B. A. (1975). Antibody-induced capping of measles virus antigens on plasma membrane studied by electron microscopy. $J$. Virol., 15, 1248-1255.

Nelson, J. M., Barker, L. F., and Danovitch, S. H. (1970). Intranuclear aggregates in the liver of a patient with serum hepatitis. (Letter). Lancet, 2, 773-774.

Nielsen, J. O., Nielsen, M. H., and Elling, P. (1973). Differential distribution of Australia-antigen-associated particles in patients with liver diseases and normal carriers. New Engl. J. Med., 288, 484-487.

Nielsen, J. O., Nielsen, M. H., and Reinicke, V. (1972). Absence of Dane particles in A-antigen carriers with a histologically normal liver. (Letter). Lancet, $2,934$.

Popper, H. and Schaffner, F. (1971). The vocabulary of chronic hepatitis. New Engl. J. Med., 284, 1154-1156.

Prince, A. M. (1968). An antigen detected in the blood during 
the incubation period of serum hepatitis. Proc. nat. Acad. Sci. (Wash.), 60, 814-821.

Ray, M. B., van Damme, B., and Desmet, V. J. (1974). Evaluation of a modified fluorescent technique for the detection of Australia antigen in liver tissue. J. immunol. Meth., 4, 47-52.

Ray, M. B. and Desmet, V. J. (1975). Immunofluorescent detection of hepatitis $\mathbf{B}$ antigen in paraffin-embedded liver tissue. J. immunol. Meth., 6, 283-289.
Ray, M. B., Desmet, V. J., Fevery, J., de Groote, J., Bradburne, A. F., and Desmyter, J. (1976). Hepatitis B surface antigen (HBsAg) in the liver of patients with hepatitis: a comparison with serological detection. J. clin. Path., 29, 89-93.

Reed, W. D., Eddleston, A. L. W. F., and Williams, R. (1974). Immunopathology of viral hepatitis in man. Progr. med. Virol., 17, 38-76.

\section{The January 1976 Issue}

\section{THE JANUARY 1976 ISSUE CONTAINS THE FOLLOWING PAPERS}

Effects of hyperthermia therapy on the liver II Morphological observations E. J. WILLS, J. M. FINDLAY, AND J. P. A. MCMANUS

Congenital hepatic fibrosis H. J. F. HODGSON, D. R. DAVIES, AND R. P. H. THOMPSON

A cause of erroneous diagnosis of pigmented villonodular synovitis R. A. BURNETT

Experience with the sodium sulphate-Alcian Blue stain for amyloid in cardiac pathology ARIELA POMERANCE, GERARD SLAVIN, AND JOSEPHINE MCWATT

Carboxyhaemoglobin dissociation in the cadaver following attempted resuscitation H. M. RICE

Serum antibodies and jejunal histology in giardiasis associated with malabsorption MARIAN J. RIDLEY AND D. S. RIDLEY

Correlation between serological and immunofluorescence results in the investigation of brucellosis in veterinary surgeons R. J. HENDERSON, D. M. HILL, A. A. VICKERS, J. M. EDWARDS, AND H. TILLETT

Slide haemagglutination test in hydatid disease: a correlative study of diagnostic procedures $\mathrm{R}$. M. MATOSSIAN, A. J. MAMO, AND R. DAKROUB

EB Virus antibody and infectious mononucleosis in a boarding school for boys T. W. HOSKINS, W. B. FLETCHER, J. M. BLAKE, M. S. PEREIRA, AND J. M. B. EDWARDS

An epidemic of diarrhoea in human neonates involving a reovirus-like agent and 'enteropathogenic' serotypes of Escherichia coli R. F. BISHOP, A. S. HEWSTONE, G. P. DAVIDSON, R. R. W. TOWNLEY, I. H. HOLMES, AND B. J. RUCK
Use of anaerobic culture for the improved isolation of Streptococcus pneumoniae R. HOWDEN

Factors affecting the assay of gentamicin by the plate diffusion method SUSAN DEACON

Plasma biotin levels in children with burns and scalds G. B. BARLOW, JENNY A. DICKERSON, AND A. W. WILKINSON

Folic acid binding protein in acute myeloid leukaemia D. W. GORST, MARY COURTIS, AND I. W. DELAMORE

A method for the differential determination of plasma antithrombins v. MUSUMECI, A. VINCENTI, AND B. BIZZI

Urinary cyclic adenosine monophosphate in young adults and elderly subjects CARLO GENNARI, MARCO GALLI, AND MARIO MONTAGNANI

An optimized semi-automatic rate method for serum glutathione reductase activity and its application to patients with malignant disease ALICE DELIDES, RICHARD J. SPOONER, DAVID M. GOLDBERG, AND FRANK E. NEAL

\section{Technical methods}

The marriage of pathology specimen tubes and request forms J. G. SALWAY

A method for distinguishing sheep erythrocytes adherent to human tissue sections R. T. ALLISON, M. SLADE, AND D. M. WALKER

Letter to the Editor

Book reviews

The Association of Clinical Pathologists: 95th general meeting

Copies are still available and may be obtained from the PUBLISHING MANAGER, BRITISH MEDICAL ASSOCIATION, TAVISTOCK SQUARE, LONDON WClH 9JR, price $£ 2.00$ 